\title{
Call for Papers: The 2nd Annual Call for papers Meeting of the European Journal of Management Studies
}

The European Journal of Management Studies (EJMS), published by Emerald, is organising its 2nd Annual Meeting, which will take place on the 7th July, 2022. This Journal is a pluralist and interdisciplinary journal, which publishes papers, case reports and book reviews related to the management of real-life organisations. Although the meeting will be in Lisbon, those participants who are not located in Portugal will be given the option of participating in the meeting through digital means over the Internet.

Papers in the following areas related to the management of organisations are welcomed:

(1) Strategy,

(2) Marketing,

(3) Human resources,

(4) Organisational behaviour,

(5) Operations and logistics,

(6) Economic sociology,

(7) Finance,

(8) Accounting,

(9) Management control,

(10) Taxation,

(11) Information management systems,

(12) Entrepreneurship,

(13) International management and

(14) Others.

No submission or enrolment fees will be levied. Papers must include a title page describing the affiliation and contacts of the author(s). Submissions should be submitted to the following e-mail address: inscricoes@advance.iseg.ulisboa.pt.

Integrated within this Meeting, we may well organise a special doctoral session, depending on the number of papers submitted by $\mathrm{PhD}$ students. Such $\mathrm{PhD}$ students should inform where they are studying to obtain their $\mathrm{PhD}$ degree when submitting their work. Acceptance to attend the Meeting does not represent a guarantee of publication in the EJMS.

(C) Mark Crathorne. Published in European Journal of Management Studies. Published by Emerald Publishing Limited. This article is published under the Creative Commons Attribution (CC BY 4.0) licence. Anyone may reproduce, distribute, translate and create derivative works of this article (for both commercial and non-commercial purposes), subject to full attribution to the original publication and authors. The full terms of this licence may be seen at http://creativecommons.org/licences/by/4.0/ legalcode

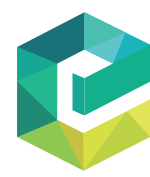

European Journal of Management Vol. 26 No. $2 / 3,2021$ pp. $131-132$ Emerald Publishing Limited e-ISSN: $2635-2648$ p-ISSN: $2183-4172$ DOI 10.1108/EJMS-11-2021-060 
Deadlines:

$26,2 / 3$

Submission date: 30th April, 2022

Decision notification to authors: 30th May, 2022

Conference: 7th July, 2022

Looking forward to seeing you in Lisbon, either in person or online. 